\title{
Evaluace pedagogického procesu osobnostního a sociálního rozvoje z pohledu výzkumu pedagogicko-psychologických jevů
}

Evaluation of pedagogical process of personal and social development from the research of pedagogical-psychological phenomena point of view

\author{
Michal Svoboda
}

\begin{abstract}
Abstrakt: Příspěvek se zamýšlí nad problematikou metodologického postupu při evaluaci pedagogického procesu osobnostního a sociálního rozvoje. Text má teoretický charakter a je strukturován do několika oblastí. V úvodu je stručně vymezen význam evaluace pedagogického procesu osobnostního a sociálního rozvoje včetně jeho možných evaluačních modelů. Za inspirativní pro evaluaci výukových programů se zaměřením na rozvoj osobnosti žáků považujeme model dle D. L. Kirkpatricka a J. D. Kirkpatricka. Těžištěm příspěvku je analýza evaluace z pohledu empirického výzkumu pedagogicko-psychologických jevů. Poslední oblastí př́spěvku je problematika validity a reliability evaluačních výsledků z evaluovaných výukových programů se zaměřením na rozvoj osobnostních a sociálních kompetencí žáků na ZŠ a SS̆.
\end{abstract}

Klíčová slova: Osobnostní a sociální rozvoj, evaluace, výzkum pedagogickopsychologických jevů

\begin{abstract}
This paper deals with the methodological issues of the evaluation of pedagogical process of Personal and Social Development. This paper has a theoretical basis and is structured into several areas. The introduction of the paper shortly characterizes the meaning of the evaluation of pedagogical process of Personal and Social Development including its possible evaluation models. The model by D. L. Kirkpatrick and J. D. Kirkpatrick is considered to be instrumental to evaluation of teaching programs focused on Personal and Social Development. The evaluation analysis from the view of empiric research of pedagogical-psychological phenomena is the focus of this paper. The last area of this contribution deals with the issue of validity and reliability of the results from the evaluated educational programs focused on Personal and Social Development of competencies of students in primary and secondary schools.
\end{abstract}

Keywords: personal and social development, evaluation, research of pedagogicalpsychological phenomena

\section{1 Úvodem - význam a modely pedagogické evaluace osobnostního a sociálního rozvoje žáků}

Cílená a systematická evaluace výukových programů se zaměřením na osobnostní a sociální rozvoj je jedním z důležitých a nepostradatelných metodických kroků. K dosažení relativně objektivních údajů při ověřování efektivity výukového programu se používá velká škála výzkumných metod. Aby uvedené metody plnily svoji funkci, musí se aplikovat 
prostřednictvím evaluačního modelu. Za inspirativní lze považovat model D. L. Kirkpatrick a J. D. Kirkpatrick (2005, s. 57-61). Tito autoři se zamýšlejí nad tím, co by výukové programy měly ovlivňovat, čeho by se konkrétně měly týkat, co může být předmětem zjišt'ování efektivity výuky apod. Evaluační model od zmiňovaných autorů zahrnuje hodnocení tréninkových aktivit a jejich účinků na několika úrovních:

- Reakce: jedná se o posouzení spokojenosti žákůs sýukovým programem;

- Učení: týká se změn v oblasti znalostí, postojů a dovedností účastníků;

- Chování: ověřuje se, zda došlo k pozitivním změnám v chování účastníků;

- Výsledky: zjišt'uje se, jaký měl výukový program vliv např. na zlepšení sociálního klimatu školní třídy.

\section{Analýza evaluace pedagogického procesu osobnostního a sociálního rozvoje z pohledu empirického výzkumu pedagogicko-psychologických jevů}

Při ověřování efektivity výukového programu je nutné postupovat stejně jako při řešení každého metodologického problému, který spadá do oblasti pedagogicko-psychologického výzkumu. V odborné literatuře (viz F. N. Kerlinger, 1972; J. Pelikán, 1998; P. Gavora, 2000; M. Chráska, 2006; aj.) můžeme najít následující složky empiricky koncipovaného výzkumu, jež se dají využít při sestavování evaluačního projektu. Jedná se o formulaci výzkumného problému, vymezování a modelování výzkumného pole, stanovování hypotéz, určování základního souboru a výběru (vzorku) aj. V následujících řádcích se pokusíme o jejich charakteristiku vaplikaci na evaluační projekty pedagogického procesu osobnostního a sociálního rozvoje:

\subsection{Formulace výzkumného problému}

V evaluačních projektech zaměřených na zjišt’ování osobnostně-sociálních předpokladů žáků můžeme využít následující typy výzkumných problémů:

- Deskriptivní (popisné) výzkumné problémy.

V evaluaci pedagogického procesu osobnostního a sociálního rozvoje mohou mít tyto výzkumné problémy následující podobu:

V čem spatřuji žáci př́nos výukového programu pro jejich osobnostní a sociální rozvoj?

Jaké zkušenosti (vědomosti, dovednosti, postoje atd.), jež si žáci osvojili v rámci absolvováni výukového programu, jsou z jejich pohledu pro život př́nosné? Aj.

Z výše uvedených otázek můžeme konstatovat, že deskriptivní výzkumné problémy mají charakter elementárního evaluačního výzkumu mapujícího jevy, které se ke zkoumané problematice vztahují. Praxe ukazuje, že evaluace pedagogického procesu osobnostního a sociálního rozvoje je na tomto typu výzkumného problému většinou založena. Rychlé a jednoduché shromažd'ování údajů na konci výukového programu nám umožňuje získat cenná data, která se prezentují v podobě absolutních či relativních četností a následně komentují. Na druhé straně takto směrovaný evaluační projekt však často neposkytuje informace o tom, zda byl výukový program opravdu efektivní. 
- Relační (vztahové) výzkumné problémy.

V oblasti evaluace pedagogického procesu osobnostního a sociálního rozvoje se u tohoto typu výzkumných problémů mohou využívat následující formulace:

Jaký je vztah mezi úspěšností výukového programu (tzn. stanovených cílù, volených metod, organizačnich forem atd.) a úrovní osvojených osobnostnich a sociálních dovedností $u$ žákù? $A j$.

- Kauzální výzkumné problémy.

Otázky tohoto typu výzkumných problémů mohou mít v evaluaci pedagogického procesu osobnostního a sociálního rozvoje následujíc podobu:

Jaký je vliv výukového programu zaměreného na vytvoření pozitivních interpersonálních vztahů mezi žáky ve tř́dní skupině na chování žáků mezi sebou v běžných "třídních“ situacích? Aj.

\subsection{Vymezení výzkumného pole}

Další významnou fází při ověřování účinnosti pedagogického procesu osobnostního a sociálního rozvoje je zmapování výzkumného pole s cílem ujasnit si rozsah i obsah vlastního výzkumného prostoru. Důležitými krokem je vymezení proměnných evaluačního výzkumu. V evaluačním projektu pedagogického procesu osobnostního a sociálního rozvoje mohou tvořit výzkumné pole následující proměnné (viz tabulka 1).

\section{Tabulka 1}

Přehled skupin proměnných, jež tvoři výzkumné pole vevaluaci pedagogického procesu osobnostního a sociálního rozvoje

\begin{tabular}{|c|c|}
\hline \multicolumn{2}{|c|}{ Přehled skupin proměnných } \\
\hline $\begin{array}{l}\text { Proměnné vztahující se } \\
\text { k osobnosti žáka: }\end{array}$ & $\begin{array}{l}\text { Proměnné vztahující se } k \\
\text { osobnosti pedagoga-lektora: }\end{array}$ \\
\hline $\begin{array}{l}\text { - } \text { věk, pohlaví } \\
\text { - } \quad \text { osobnostní vlastnosti } \\
\text { - } \quad \text { úroveň sebepojetí žáka } \\
\text { - } \quad \text { úroveň osobnostních a sociál. dovedností } \\
\text { - } \text { míra psychické odolnosti } \\
\text { - } \text { míra fyzické odolnosti } \\
\text { - } \quad \text { očekávání a postoje k výuk. programu } \\
\text { - } \text { motivace k účasti } \\
\text { - } \quad \text { angažovanost žáků } \\
\text { - } \quad \text { aj. }\end{array}$ & $\begin{array}{l}\text { - } \text { věk, pohlaví } \\
\text { - } \text { osobnostní vlastnosti } \\
\text { - úroveň osobnostních a sociál. dovedností } \\
\text { - } \text { teoretické znalosti } \\
\text { - praktické dovednosti } \\
\text { - } \text { předešlé zkušenosti } \\
\text { - styly řízení a vedení } \\
\text { - sehranost týmu pedagogů-lektorů } \\
\text { - úroveň kreativity } \\
\text { - aj. }\end{array}$ \\
\hline $\begin{array}{l}\text { Proměnné vztahující se k výukové skupině: } \\
\text { - } \quad \text { kvalita interpersonálních vztahů ve skupině } \\
\text { - } \quad \text { koheze skupiny } \\
\text { - } \quad \text { složení skupiny (pohlaví, věk, vzdělání apod.) } \\
\text { - } \quad \text { postoj účastníků ke skupině aj. } \\
\text { - } \quad \text { velikost skupiny } \\
\text { - } \quad \text { délka trvání skupiny } \\
\text { - } \quad \text { aj. }\end{array}$ & $\begin{array}{l}\text { Proměnné vztahující se k cílům výuky: } \\
\text { - osobnostní rozvoj účastníků } \\
\text { - rozvoj sociálních dovedností } \\
\text { - formování sociální skupiny } \\
\text { - } \quad \text { pozitivní ovlivňování sociálního klimatu ve } \\
\text { - skupině } \\
\text { - aj. }\end{array}$ \\
\hline $\begin{array}{l}\text { Proměnné vztahující se k organizačním formám a } \\
\text { metodám (technikám): } \\
\text { - délka výukového programu }\end{array}$ & $\begin{array}{l}\text { Další proměnné: } \\
\text { - širší prostředí výuky } \\
\text { - technické a materiální vybavení }\end{array}$ \\
\hline
\end{tabular}


- $\quad$ výukové prostory

- použitá metoda a organizační forma

- náročnost metod a organizačních forem

- $\quad$ řazení jednotlivých metod a organizačních forem

- aj.

Proměnné lze ve výzkumném poli evaluačního projektu vymezit jednak z pohledu jejich vzájemného vztahu (závisle proměnné, nezávisle proměnné), jednak z pohledu pořadí, jež zaujímají v pedagogickém procesu (vstupní proměnné, intervenující [výukové] proměnné a výstupní proměnné). Celé schéma vztahů a pořadí jednotlivých proměnných v evaluačním projektu pedagogického procesu osobnostního a sociálního rozvoje můžeme ve formě zjednodušeného modelu výzkumného pole znázornit graficky (viz obrázek 1).

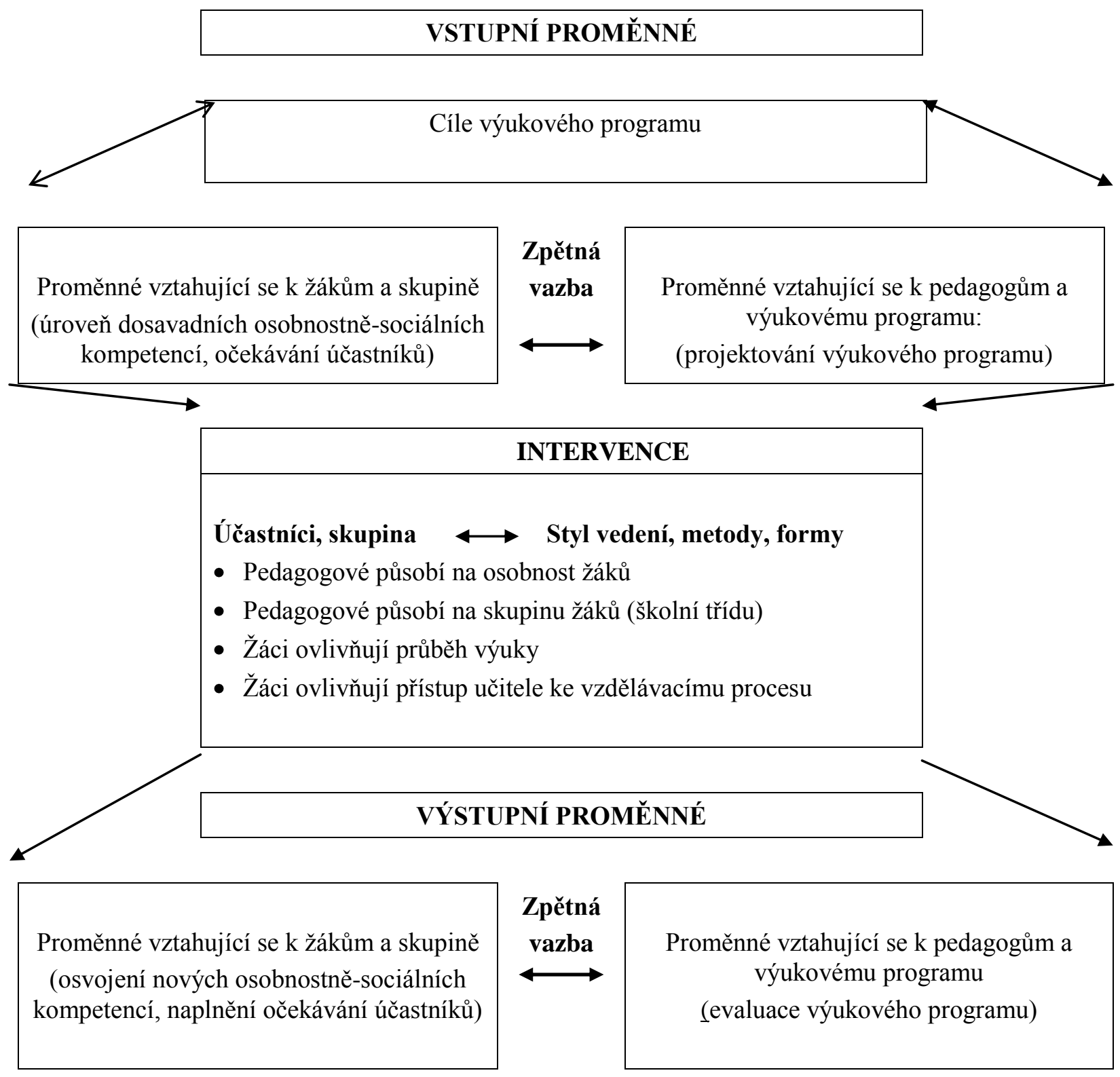

Obrázek 1. Grafické znázornění zúženého evaluačního výzkumného pole z pohledu vztahů mezi jednotlivými proměnnými a jejich pořadím v pedagogickém procesu. 


\subsection{Formulace hypotéz}

Další etapou v ověřování efektivity výukového programu osobnostního a sociálního rozvoje je formulace výzkumných hypotéz. Jako príklad uvádíme následující formulace hypotéz patřící do oblasti evaluačních výzkumů pedagogického procesu osobnostního a sociálního rozvoje:

- Hypotézy vyjadřující rozdíly (prríklad hypotéz):

Žáci 4. ročniků SOŠ (ekonomika, podnikáni) považují výukové programy osobnostního a sociálního rozvoje pro jejich profesni př́pravu za př́nosnějši než žáci 1. ročníkủ SOŠ (ekonomika, podnikání).

- Hypotézy vyjadřující vztahy (př́iklad hypotéz):

Mezi konkrétními očekáváními účastníki̊ a jejich úrovní osvojení osobnostních a sociálních dovedností je pozitivni vztah.

- Hypotézy vyjadřující následky (prríklad hypotéz):

Čim více hodin, více dní, žáci absolvovali výukový program osobnostního a sociálního rozvoje, tím úspěšněji dokáží řš̌it intrapersonální a interpersonálni situace ve svém životě.

Na výše uvedené formulace hypotéz z oblasti evaluace pedagogického procesu osobnostního a sociálního rozvoje je vhodné pohlížet jako na př́íklady, které v teoretické rovině ukazují rozdíly mezi jednotlivými typy hypotéz. Každá hypotéza, jež je využita př́mo v reálném evaluačním projektu, by měla být pečlivě zvažována, např. jestli je v kontextu s naformulovaným výzkumným problémem; zda je hodnotná, respektive zda nezjišt’uje něco, co je všeobecné známé; jestli je zjistitelná z pohledu výzkumných možností apod. Hypotézy, které jsme naformulovali jako př́klad pro jednotlivé typy hypotéz, nezjišt'ují jenom efektivitu výukového programu, ale zabývají se tím, proč $\mathrm{k}$ určitému jevu ve výukovém programu došlo. Zastáváme názor, že plnohodnotná evaluace výuky osobnostního a sociálního rozvoje by měla mít přesahující charakter. Neměla by pouze zjišt'ovat, čeho se výukovém programu docílilo, např. prŕmými otázkami typu: „,Jaké nové vědomosti a dovednosti jste získali?, “ ale měla by se zabývat také tím, proč a čím byly změny způsobeny apod.

\section{Závěr - výzkumné metody, validita a reliabilita}

Součástí evaluace pedagogického procesu osobnostního a sociálního rozvoje je volba evaluačních metod a problematika validity a realiability. Z charakteru evaluačního projektu zaměřeného na zjišt'ování efektivity pedagogického procesu osobnostního a sociálního rozvoje se domníváme, že mezi výzkumné metody, jež mají v evaluaci výukového programu široké a plnohodnotné využití patří: explorační metody, ratingové metody, testové metody, metody měření sociálních vztahů a behaviorální metody. K problematice validity se vztahuje otázka, zda v evaluačních projektech výukových programů osobnostního a sociálního rozvoje je skutečně zjišt’ována efektivita výuky, anebo jsou postihovány jevy, které vypovídají jenom o její charakteristice a průběhu. Některé otázky využívané v evaluaci, např. Jak jste s průběhem výukového programu spokojeni?, vypovídají o tom, jaký vztah účastníci zaujímají $\mathrm{k}$ výukovému programu, ale př́mo nevypovídají o samotných výsledcích výukového programu v oblasti rozvoje osobnostních a sociálních dovedností. Za nejzávažnější problém v oblasti validity výsledků evaluačního šetření pedagogického procesu osobnostního a sociálního rozvoje lze považovat predikčnost. Jestliže závěry evaluačního šetření vypovídají o dosažení požadované efektivity ve výukovém programu, pak by účastníci měli být v běžném životě úspěšní co se osobnostních a sociálních dovedností týče. Ovšem zjistit, zda platí a 
funguje vzorec: úspěšný žák ve výukovém programu osobnostního a sociálního rozvoje rovná se úspěšný žák v osobním a společenském životě, je z praktického hlediska skoro nemožné. Další kritériem určujícím plnohodnotnost evaluačních závěrů je reliabilita. Při využívání vhodných standardizovaných nástrojů v evaluaci pedagogického procesu osobnostního a sociálního rozvoje bývá realiability většinou dosahováno. Naopak při využívání nástrojů, jež byly vytvořeny pro měření konkrétního výukového programu bez řádné standardizace (jedná se o většinu nástrojů, jež jsou využívány v běžné školní praxi), je nutné výsledky interpretovat $\mathrm{s}$ větší opatrností a s přihlédnutím $\mathrm{k}$ tomuto faktu.

\section{Literatura}

Gavora, P. (2000). Úvod do pedagogického výzkumu. Brno: Paido.

Hermochová, S., Komárková, R., Slaměník, I., \& Výrost, J. (2001). Aplikovaná sociální psychologie III. Praha: Grada.

Chráska, M. (2006). Úvod do pedagogického výzkumu. Olomouc: UP v Olomouci.

Kerlinger, F. N. (1972). Základy výzkumu chování. Praha: Academia.

Kirkpatrick, D. L., \& Kirkpatrick, J. D. (2005). Transfering learning to behavior. San Francisco: Berrett-Koehler Publisher.

Maňák, J., \& Švec, V. (2003). Výukové metody. Brno: Paido.

Pelikán, J. (1998). Základy empirického výzkumu pedagogických jevů. Praha: Karolinum.

Svoboda, M. (2010). Analýza metod, organizačnich forem a evaluace osobnostního a sociálního rozvoje ve výchovných a vzdělávacích programech základnich a středních škol. (Disertační práce). Praha: FF UK.

Švec, Š. et al. (2009). Metodologie věd o výchově. Brno: Paido.

\section{Kontakt}

PhDr. Michal Svoboda, Ph.D.

Západočeská univerzita v Plzni

Fakulta pedagogická, Katedra psychologie

Klatovská 51, 30614 Plzeň

e-mail: msvoboda@kps.zcu.cz

\section{Bibliografické údaje}

Svoboda, M. (2011). Evaluace pedagogického procesu osobnostního a sociálního rozvoje z pohledu výzkumu pedagogicko-psychologických jevů. In T. Janík, P. Knecht, \& S. Šebestová (Eds.), Smišený design v pedagogickém výzkumu: Sbornik př́spěvkỉ z 19. výroční konference České asociace pedagogického výzkumu (s. 103-108). Brno: Masarykova univerzita.

Dostupné z: http://www.ped.muni.cz/capv2011/sbornikprispevku/svoboda.pdf

doi: 10.5817/PdF.P210-CAPV-2012-74 